\title{
The Impact of the Hybridoma Technology on the R\&D of Idiotypic Antibodies
}

\author{
Heinz Kohler
}

The PubMed data set was scanned with the title and abstract term "Idiotype" followed by secondary searches with "Vaccine" and "Clinical trial." The retrieved references were analyzed from the period before and after hybridoma technology (1975). In 1963, Oudin and Kunkel discovered that antibodies against antibodies can be raised to identify determinants unique to an antibody termed idiotype or individual antigenic determinant. Two laboratories reported that anti-idiotypic antibodies can suppress specific antibody responses in mice. In 1974, Jerne proposed a network of idiotypes and anti-idiotypes and the functionality of the idiotype network was confirmed. This prompted the proposal of a symmetrical regulatory immune response. By 1989, the concept and the functional parameters of the immune idiotype network were established in the prehybridoma period. It was not until 1981 that monoclonal anti-idiotypic antibodies were used as tools to study the expression of idiotypic determinants on antibodies and to categorize functional properties in the immune network as network antigens in 1989. Hybridoma-generated monoclonal anti-idiotypic antibodies provided the tools to precisely identify different idiotypic regions on antibodies and test these as targets to induce network cascades. The initial distinction of $\mathrm{Ab} 2 \mathrm{~s}$ as alpha and beta were expanded to include gamma and delta. The initial concept of Ab2beta being an antigen internal image, used as vaccine, was challenged showing that targeting all idiotopes on B cell receptors can induce specific antibodies. After the discovery of the hybridoma technology a wave of idiotype topic publications occurred, that declined by 2015. In 1985, in this wave of reports on anti-idiotypes, their importance to vaccines dominated. These vaccines targeted in animal models parasite, bacterial, and viral diseases, and cancer. The reported data indicated a therapeutic response in inbred mice. The issue of idiotype matching between mouse haplotypes of vaccine origin and treated mice were raised. In 1995, the human clinical trials in different cancers using anti-Id vaccines were reported. Only one such vaccine received conditional approval in Argentina and Cuba, whereas the other trials failed in phase II and III. The reasons for this failure were subsequently discussed. Although the use of the Milstein and Kohler hybridoma technology and subsequently alternative methods to produce monoclonal animal and human antibodies created a new class of drugs, commonly referred as "Biological," it failed on the promise therapeutic of anti-Id vaccines.

Keywords: idiotypic antibodies, human clinical trials, hybridoma technology

\section{Introduction}

T HE DISCOVERY OF monoclonal antibodies was facilitated by NATURE with the disease of multiple myeloma. Waldenstrom described a bone marrow tumor that produces a macroglobulin (IgM). ${ }^{(1)}$ Bence-Jones protein in urine of multiple myeloma patients was another "natural" source of monoclonal Ig light chain. ${ }^{(2,3)}$ Subsequent reports showed the primary and three-dimensional structure of immunoglobulins. ${ }^{(4-6)}$ Whereas these structural studies were done on immunoglobulins from human B cell tumors, Potter developed a method to induce plasmacytomas in inbred mice that exhibited antigen binding. ${ }^{(7)}$ The study of a group of mouse monoclonal antibodies with specificity for phosphoryl choline and a shared idiotypic specificity marked the beginning of intensive idiotypy investigations. $^{(8)}$

\section{The Time Before the Hybridoma Technology}

To appreciate the impact of the hybridoma technology on the field of idiotypy one should describe the landscape of idiotype R\&D at the time before Kohler and Milstein. ${ }^{(9)}$ The primary task of antibodies is providing immune defense against pathogens. Thus, why would Nature turn antibodies against each other? The mechanism of antibody against antibody implicit in idiotype network appears unnatural. And why would such activity be involved in the regulation of immune response?

Department of Microbiology and Immunology, University of Kentucky, Lexington, Kentucky, USA. 
Hints of immune homeostasis were found as early as 1964 by Rowley and Fitch. ${ }^{(10)}$ Passive injection of homologous antisheep erythrocyte serum inhibited a primary antibody response. The authors conclude that the formation of specific antibody may provide a homeostatic or "feedback" mechanism affecting the B cell receptor (BCR) being itself antibody.

The discussions of anti-antibodies started in $1957^{(11)}$ and continued in 1964. ${ }^{(12)}$ Oudin and Michel ${ }^{(13,14)}$ studied antiallotypy in rabbits and discovered a new type of antiantibody that he termed anti-idiotype. It should be noted that none of these anti-idiotypic antibodies could be induced in the rabbit that was immunized to produce antiidiotypic antibodies. Thus, these anti-idiotypic antibodies are not autoantibodies.

Although these conceptional studies continued, much progress was made in the field of immunoglobulin structure of multiple myeloma proteins, so-called paraproteins. ${ }^{(2-5,15-18)}$ Potter devised a method to induce plasmacytomas in Blab/c mice with antigenic specificity. ${ }^{(19)}$ That provided a new source of monoclonal antibodies for structural and three-dimensional studies. ${ }^{(20,21)}$ Among these Balb/c mouse monoclonal antibodies was a group of antibodies against phosphoryl-choline with shared idiotype specificity. ${ }^{(8)}$

In 1973, Jerne ${ }^{(22)}$ speculated on a network of interacting lymphocytes and antibodies, which he expanded in 1974. ${ }^{(22)}$ The immune network theory became very popular creating a wave of anti-Id R\&D (Fig. 1). Experimental support was obtained by demonstrating an auto-anti-Id response after an immune response. ${ }^{(23,24)}$ These findings let to the proposal of a symmetrical immune response of Id and anti-Id. ${ }^{(25,26)}$ By 1975, the theoretical and experimental aspects in the idiotype landscape were completed.

\section{The Time After the Hybridoma Technology}

The new technology of making monoclonal antibodies against selected targets ${ }^{(9)}$ boosted the work on idiotypes (Fig. 1). It was now possible to generate monoclonal anti-idiotypic antibodies. With these new tools the individual idiotypic determinants (idiotope) were dissected and the topography and network function of antibodies could be studied. ${ }^{(27-30)}$ Interestingly, monoclonal anti-Id blocking the antigen binding (Ab2alpha) and not blocking monoclonals (Ab2beta) stimulated anti-phosphorylcholine $\mathrm{B}$ cell $^{(31)}$ challenging the "internal image" concept of Jerne. ${ }^{(32)}$

Although the basic research on idiotype network continued, a new aspect emerged in the field of immunotherapy. Supported by the reports that anti-Id antibody can suppress B cells, ${ }^{(33)}$ Levy and colleagues ${ }^{(34)}$ prepared a monoclonal anti-Id against a patient's B cell tumor and used it to suppress the idiotype expressing tumor. This approach led to a new concept in immunotherapy ${ }^{(35)}$ and to a startup Biotech company devoted to passive and active anti-Id therapy (IDEC Pharmaceuticals), which eventually brought the first cancer-directed chimeric antibody Rituxan to market. The hybridoma technology was quickly exploited to produce monoclonal antiidiotypic antibodies as so-called internal antigen images (Fig. 2). Monoclonal anti-Id antibodies of the Ab2beta type were tested in animal models against viral and bacterial infections and cancers. ${ }^{(36-42)}$ These anti-idiotype experiments in animals did induce antigen-specific responses and vaccineinduced protection was also observed.

The positive results in animal models were encouraging to use cancer targeting anti-Ids in clinical trials (Fig. 3). Several reports on human trials with monoclonal anti-idiotype antibodies

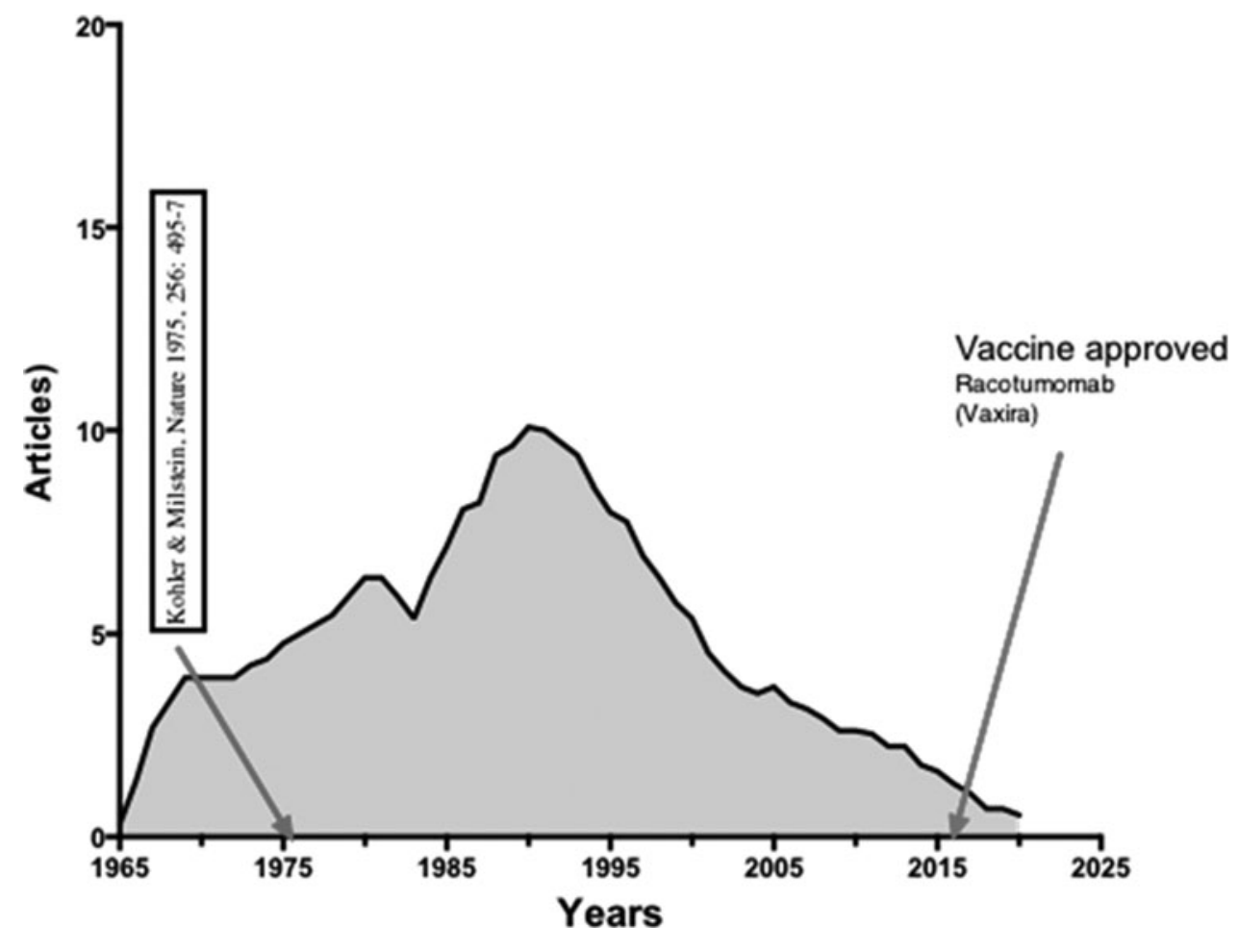

FIG. 1. Plot of a PubMed search with the search terms idiotype and anti-idiotype. The area under the line represents the search return at given year. The year of the Milstein/Kohler publication is indicated as well as the year of an anti-Id vaccine approval. 


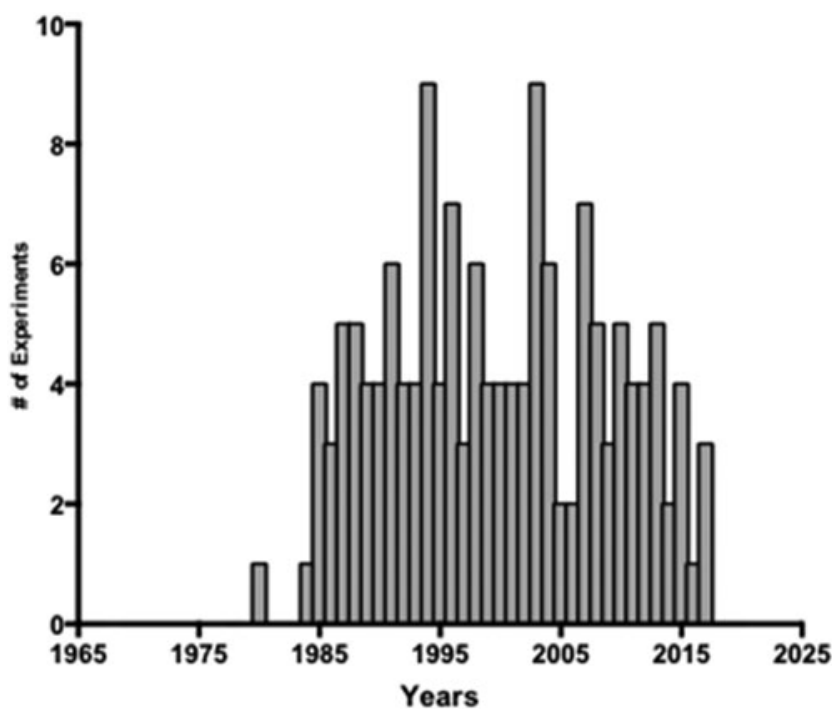

FIG. 2. The data of search in Figure 1 were search with the term of anti-Id vaccine. Each bar represents the number of vaccine experiments per year.

appeared between 1992 and 2018 (Fig. 3). The patient's response in these trials has been recently reviewed. ${ }^{(43)}$ Only one monoclonal anti-Id vaccine was approved as drug against tumors in Cuba and Argentina. It was argued that the failure of anti-Id vaccines in human trials is due to the narrow and mismatched idiotypes between the origin and vaccine target idiotype. ${ }^{(44)}$ This conclusion is supported by data reported by Brown and Sealy. ${ }^{(4)}$ The authors generated five monoclonal anti-idiotype against a dominant anti-p-phenylarsonate (ars) monoclonal. Each anti-Id did not compete in binding to the antiars monoclonal. Furthermore, each anti-Id suppressed on a portion of the total anti-ars response indicating a multitude of different idiotypes in the anti-ars response of different strains of mice. In contrast, in previous experiments ${ }^{(46)}$ complete suppression of the anti-ars response was achieved with polyclonal anti-idiotype antibody. Realizing the diversity of idiotypes in the BCR repertoire responding to a given antigen effective stimulation would require an equally diverse anti-Id pool. Thus, the proposal was made to target multiple idiotopes on BCR using pools of polyclonal anti-idiotype antibodies as vaccine. ${ }^{(47,48)}$

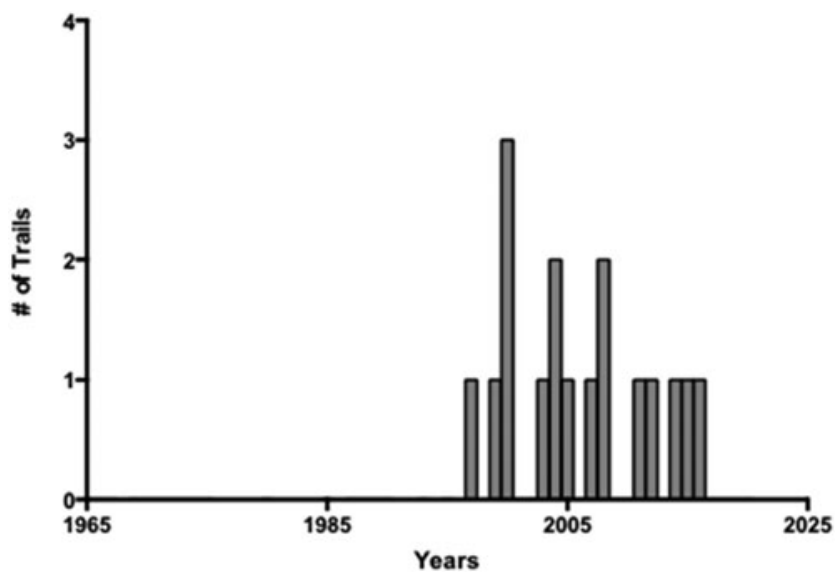

FIG. 3. The data in Figure 1 were search with the term human anti-Id trial.

\section{Conclusion}

At the time the hybridoma technology emerged most of the functional and theoretical aspects of the idiotype paradigm had been known. The means to produce monoclonal antibodies was quickly realized to produce monoclonal anti-idiotypic antibodies. These were used to study the topography of idiotopes on antibodies and to dissect antigen-induced network responses. The major impact of the new technology was the field of therapeutic idiotype vaccines, based on the "internal image" concept. The induction of specific antibody response using monoclonal anti-idiotypes was documented in animal models. However, idiotype-based therapeutic vaccines failed in the clinic except for one in South America approved. An emerging change of the understanding the idiotype network led to the proposal of abandoning monoclonal antibodies and using polyclonal idiotype vaccines.

\section{Author Disclosure Statement}

No competing financial interests exist.

\section{Funding Information}

No funding was received for the preparation of the manuscript.

\section{References}

1. Waldenstrom J: Abnormal proteins in myeloma. Adv Intern Med 1952;5:398-440.

2. Hilschmann N, and Craig LC: Amino acid sequence studies with Bence-Jones proteins. Proc Natl Acad Sci U S A 1965; 53:1403-1409.

3. Titani K, Whitley E, Jr., Avogardo L, and Putnam FW: Immunoglobulin structure: Partial amino acid sequence of a Bence Jones protein. Science 1965;149:1090-1092.

4. Rutishauser U, Cunningham BA, Bennett C, Konigsberg WH, and Edelman GM: The covalent structure of a human gamma G-immunoglobulin. 8. Amino acid sequence of heavy-chain cyanogen bromide fragments H5-H7. Biochemistry 1970;9:3171-3181.

5. Shimizu A, Paul C, Kohler H, Shinoda T, and Putnam FW: Variation and homology in the mu and gamma heavy chains of human immunoglobulins. Science 1971;173:629-633.

6. Poljak RJ, Amzel LM, Avey HP, Chen BL, Phizackerley RP, and Saul F: Three-dimensional structure of the Fab' fragment of a human immunoglobulin at 2,8-A resolution. Proc Natl Acad Sci U S A 1973;70:3305-3310.

7. Potter M, and Boyce CR: Induction of plasma-cell neoplasms in strain BALB/c mice with mineral oil and mineral oil adjuvants. Nature 1962;193:1086-1087.

8. Potter M, and Lieberman R: Common individual antigenic determinants in five of eight BALB-c IgA myeloma proteins that bind phosphoryl choline. J Exp Med 1970;132:737-751.

9. Kohler G, and Milstein C: Continuous cultures of fused cells secreting antibody of predefined specificity. Nature 1975;256:495-497.

10. Rowley DA, and Fitch FW: Homeostasis of antibody formation in the adult rat. J Exp Med 1964;120:987-1005.

11. Milgrom F, and Dubiski S: [Mechanism of auto-immunization during hemolytic anemia]. Sang 1957;28:11-23.

12. Gell PG, and Kelus AS: Anti-antibody or clone-product? Nature 1964;201:687-689.

13. Oudin J, and Michel M: [A new allotype form of rabbit serum gamma-globulins, apparently associated with anti- 
body function and specificity]. C R Hebd Seances Acad Sci 1963;257:805-808.

14. Oudin J, and Michel M: Idiotypy of rabbit antibodies. I. Comparison of idiotypy of antibodies against Salmonella typhi with that of antibodies against other bacteria in the same rabbits, or of antibodies against Salmonella typhi in various rabbits. J Exp Med 1969;130:595-617.

15. Waldenstrom J: Pathological globulins and protein synthesis. Exp Med Surg 1954;12:187-191.

16. Porter RR: Separation and isolation of fractions of rabbit gamma-globulin containing the antibody and antigenic combining sites. Nature 1958;182:670-671.

17. Milstein C: Variations in amino-acid sequence near the disulphide bridges of Bence-Jones proteins. Nature 1966;209:370 373.

18. Hilschmann N: [Chemical structure of 2 kappa-type Bence Jones proteins (Roy and Cum.)]. Hoppe Seylers Z Physiol Chem 1967;348:1077-1080.

19. Potter M, and Robertson CL: Development of plasma-cell neoplasms in BALB/c mice after intraperitoneal injection of paraffin-oil adjuvant, heart-killed Staphylococcus mixtures. J Natl Cancer Inst 1960;25:847-861.

20. Segal DM, Padlan EA, Cohen GH, Rudikoff S, Potter M, and Davies DR: The three-dimensional structure of a phosphorylcholine-binding mouse immunoglobulin Fab and the nature of the antigen binding site. Proc Natl Acad Sci U S A 1974;71:4298-4302.

21. Rudikoff S, Satow Y, Padlan E, Davies D, and Potter M: Kappa chain structure from a crystallized murine Fab': Role of joining segment in hapten binding. Mol Immunol 1981;18:705-711.

22. Jerne NK: The immune system. Sci Am 1973;229:52-60.

23. Kluskens L, and Kohler H: Regulation of immune response by autogenous antibody against receptor. Proc Natl Acad Sci U S A 1974;71:5083-5087.

24. Cosenza H: Detection of anti-idiotype reactive cells in the response to phosphorylcholine. Eur J Immunol 1976;6:114-116.

25. Kohler H: The response to phosphorylcholine: Dissecting an immune response. Transplant Rev 1975;27:24-56.

26. Kohler $\mathrm{H}$, and Nara P: A novel hypothesis for original antigenic $\sin$ in the severe disease of SARS-CoV-2 infection. Monoclon Antib Immunodiagn Immunother 2020;39: 107-111.

27. Kearney JF, Barletta R, Quan ZS, and Quintans J: Monoclonal vs. heterogeneous anti-H-8 antibodies in the analysis of the anti-phosphorylcholine response in BALB/c mice. Eur J Immunol 1981;11:877-883.

28. Kearney JF, Pollok BA, and Stohrer R: Analysis of idiotypic heterogeneity in the anti-alpha 1-3 dextran and antiphosphorylcholine responses using monoclonal anti-idiotype antibodies. Ann N Y Acad Sci 1983;418:151-170.

29. Stohrer R, and Kearney JF: Fine idiotype analysis of B cell precursors in the $\mathrm{T}$-dependent and $\mathrm{T}$-independent responses to alpha 1-3 dextran in BALB/c mice. J Exp Med 1983;158:20812094.

30. Wittner MK, Bach MA, and Kohler H: Immune response to phosphorylcholine. IX. Characterization of hybridoma antiTEPC15 antibodies. J Immunol 1982;128:595-599.

31. Huang JH, Ward RE, and Kohler H: Idiotope antigens (Ab2 alpha and $\mathrm{Ab} 2$ beta) can induce in vitro $\mathrm{B}$ cell proliferation and antibody production. J Immunol 1986;137:770-776.

32. Jerne NK: Towards a network theory of the immune system. Ann Immunol (Paris) 1974;125C:373-389.
33. Cosenza H, and Kohler H: Specific suppression of the antibody response by antibodies to receptors. Proc Natl Acad Sci U S A 1972;69:2701-2705.

34. Hatzubai A, Maloney DG, and Levy R: The use of a monoclonal anti-idiotype antibody to study the biology of a human B cell lymphoma. J Immunol 1981;126:2397-2402.

35. Meeker TC, Lowder J, Maloney DG, Miller RA, Thielemans K, Warnke R, and Levy R: A clinical trial of antiidiotype therapy for B cell malignancy. Blood 1985;65: 1349-1363.

36. Kennedy RC, Melnick JL, and Dreesman GR: Antibody to hepatitis B virus induced by injecting antibodies to the idiotype. Science 1984;223:930-931.

37. McNamara MK, Ward RE, and Kohler H: Monoclonal idiotope vaccine against Streptococcus pneumoniae infection. Science 1984;226:1325-1326.

38. Grzych JM, Capron M, Lambert PH, Dissous C, Torres S, and Capron A: An anti-idiotype vaccine against experimental schistosomiasis. Nature 1985;316:74-76.

39. Bona $\mathrm{C}$, and Moran T: Idiotype vaccines. Ann Inst Pasteur Immunol (1985) 1985;136C:299-312.

40. Raychaudhuri S, Saeki Y, Fuji H, and Kohler H: Tumor-specific idiotype vaccines. I. Generation and characterization of internal image tumor antigen. J Immunol 1986;137:1743-1749.

41. Herlyn D, Wettendorff M, Schmoll E, Iliopoulos D, Schedel I, Dreikhausen U, Raab R, Ross AH, Jaksche H, and Scriba M.: Anti-idiotype immunization of cancer patients: Modulation of the immune response. Proc Natl Acad Sci U S A 1987;84:8055-8059.

42. Tanaka M, Sasaki N, and Seto A: Induction of antibodies against Newcastle disease virus with syngeneic anti-idiotype antibodies in mice. Microbiol Immunol 1986;30:323-331.

43. Kohler H, Pashov A, and Kieber-Emmons T: The promise of anti-idiotype revisited. Front Immunol 2019;10:808.

44. Chen JJ, Saeki Y, and Kohler H: Idiotype matching: correlation of expression of protective idiotype in sera with survival of tumor mice. J Immunol 1990;144:759-764.

45. Brown AR, and Sealy RE: Regulation of the BALB/c antip-azophenylarsonate antibody response by monoclonal anti-idiotype. II. Idiotope expression in serum and its regulation. J Immunol 1986;137:610-617.

46. Hart DA, Wang AL, Pawlak LL, and Nisonoff A: Suppression of idiotypic specificities in adult mice by administration of antiidiotypic antibody. J Exp Med 1972;135:1293-1300.

47. Kohler H, Pashov AD, and Kieber-Emmons T: Commentary: Immunology's coming of age. Front Immunol 2019;10:2175.

48. Stanova AK, Ryabkova VA, Utekhin SV, Shoenfeld VJ, Churilov LP, and Shoenfeld Y: Anti-idiotypic agonistic antibodies: Candidates for the role of universal remedy. Antibodies (Basel) 2020;9:19.

Address correspondence to: Heinz Kohler, MD, PhD Department of Microbiology and Immunology University of Kentucky 5235 Athens Boonesboro Road Lexington, KY 40509

USA

E-mail: hkohl00@uky.edu

Received: December 14, 2020 Accepted: December 16, 2020 